\title{
Internationalization @ home in Engineering Education: Enhancing Social Capital in English-taught Master's Programmes
}

\section{Natascha Strenger, Nilgün Ulbrich}

Project ELLI2, Department of Mechanical Engineering, Ruhr-Universität Bochum, Germany.

\begin{abstract}
German higher education institutions attract students from all over the word for degree mobility, especially after the Bologna reform has led to an increase in internationally-oriented, English-taught study programmes. With such programmes, universities serve the politically intended purpose of attracting highly qualified talent in the form of international graduates that might potentially stay for the German job market. But for the transition from studies to the work market to be successful, it is essential for international students to acquire social capital in the form of contacts to people from the host country.

This paper firstly presents results of a study on the situation of students who come to study in international engineering programmes at the RuhrUniversität Bochum in Germany, focusing on the unsatisfactory contact situation of international and German students revealed in the study. Secondly, measures of the project ELLI2 - Excellent Teaching and Learning in Engineering Sciences - are introduced that aim at improving this situation, fascilitating contact between German and international engineering students. The set-up of a tandem-programme is presented, as well as participation structure and evaluation results of the first two runs of this programm in 2017/18. In addition, an international student council network will be introduced.
\end{abstract}

Keywords: Engineering Education; Internationalization at home; Bologna reform; Globalization; Social Capital. 


\section{Introduction}

Since the Bologna reform, the implementation of a two-stage system of study programmes has made great progress in Germany. The influence of globalization tendencies on the German higher education system has also led to a wide-spread development of international study programmes, particularly master degree courses. Today, there are more than 1,100 internationally oriented programmes on the master's level and 160 international Bachelor programmes in Germany: German Academic Exchange Service, DAAD (2019). The engineering disciplines were among the first to implement international (English-taught) programmes, partly in order to make up for their shrinking student numbers in the final years of the old millennium: Maiworm (2002). Great potential is seen in such programmes to attract talent from all over the world, possibly with the perspective of staying on to work in the German labour market, especially in the much sought-after technical fields of study.

At the engineering faculties of the Ruhr-Universität Bochum (RUB), the Project ELLI2 aims at improving the conditions of teaching and learning in engineering education. The cooperative project of three German universities started off in 2011 and is funded within the "Qualitätspakt Lehre” (Teaching Quality Pact by the German Federal Government and States). The project's key area Globalization takes into account the latest challenges for internationalization and diversity in higher education contexts. The central goal of all its measures is to add an international component to higher education in engineering sciences by increasing the dialogue between international and local students in and around study programmes, for example by shared events and lectures.

In 2014 and 2015, the project had conducted workshops and qualitative interviews with the study coordinators and heads of the RUB's three international master's programmes in engineering sciences, identifying challenges of international study programmes and elaborating concepts to improve the contact situation of international and German students in such programmes. The results of this preliminary study were presented at the second HEAd conference: Strenger; Frerich (2016).

This paper gives an overview of a follow-up investigation of the student's view that was based on those preliminary results and realized via a quantitative survey and qualitative interviews among the international master's students. It furthermore presents different approaches of internationalization at home which the project ELLI2 has implemented in 2017 and 2018 in cooperation with the RUB engineering faculties. These measures deal with the challenges identified and aim at increasing the possibilities for international engineering students to acquire social capital through contact with German students. 


\section{Problem: Lack of Social Capital in International Master's Programmes}

At the RUB, the three engineering faculties Mechanical Engineering, Electrical Engineering and Civil and Environmental Engineering hold a total of 10 study programmes, including three internationally-oriented Master degree courses, which are taught $100 \%$ in English: Laser and Photonics, Computational Engineering and Materials Science and Simulations. Although they are open to German and international students alike, the student body of these three programmes comprises hardly any Germans. Most students are from (East) Asia, the main countries of origin being India, Pakistan, Syria, China and Iran.

The preliminary investigation in 2014 and 2015 had focused on the faculties reasons for implementing such international programmes, revealing a strong interest to gain potential doctoral students in highly specialized fields that were rarely chosen by German engineering graduates. With regard to the study situation of the international students, one of the central hypotheses derived from the interviews with study coordinators was that, due to the distribution of nationalities in the programme, contact opportunities with the host country would be scarce, thus limiting the possibilities of acquiring social capital. (Social capital, according to the late French sociologist Pierre Bourdieu, comprises all social, societal and familiar relations which can occur in a more or less institutionalized form and rely on social acts of exchange to be converted, e.g. into economic capital in the form of job opportunities through contacts to employers: Bourdieu (1983).)

In order to test this hypothesis from the students' point of view, a two-stage investigation was conducted in 2016, that comprised a quantitative online-survey with 84 participants and a follow-up study with a total of 17 semi-structured, qualitative interviews that served to either confirm or disprove the survey results: Strenger (2019).

\subsection{Results of the investigation}

As indicators for opportunities to accumulate social capital during their studies in Germany, the participants of the survey were asked how much contact they have to a) international students (except students from their own home country), b) students from their home country and c) German students (on a scale from 1-7, 1 meaning "very much contact", 7 "no contact at all). The results indicate a clear lack of contact to Germans: 
In the context of your studies at RUB, how much contact do you have with...

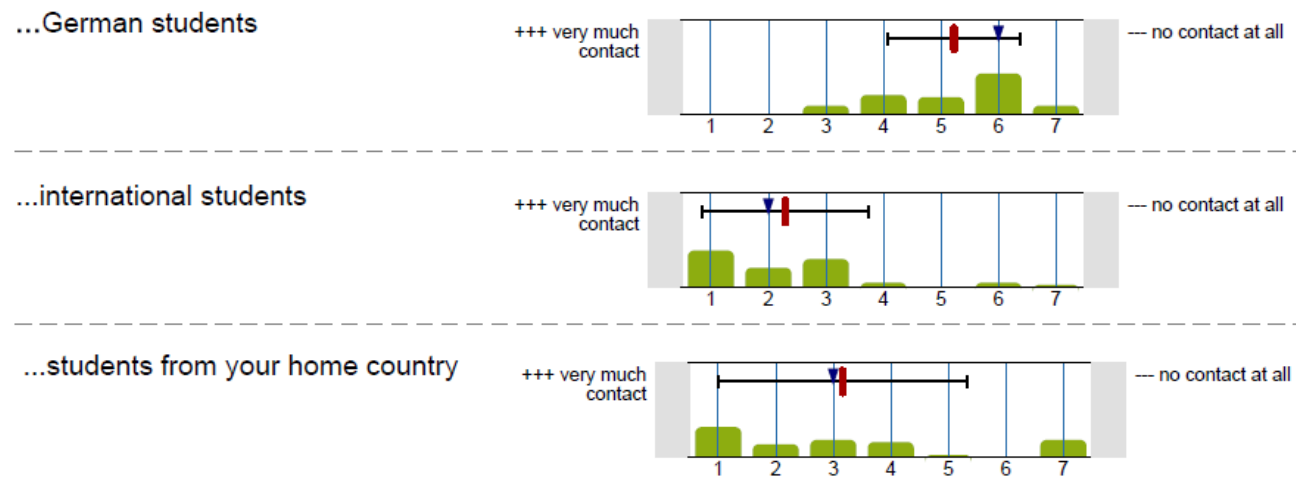

Figure 1. Contact situation of international students in English-taught programmes. Source:Strenger (2019).

Only one person states to have very much contact to German students. The cumulative percentage of contact to Germans reaches $23 \%$ on the first three ranks, while a total of $40 \%$ state that they have no contact at all (10\%), or almost no contact at all to German students. $36 \%$ state to have very much contact to international students, with a cumulative percentage of $85 \%$ on the first three ranks. $32 \%$ state that they have very much contact to students from their own home country, the cumulative percentage amounting to $69 \%$ on the first two ranks.

Asked with which one of these three groups students have the most contact, $56 \%$ state that they are mostly in contact with international students and $43 \%$ state that they have the most contact to students from their own home country. Only $1 \%$ of all international students state that they are mostly in contact with German students while studying in Germany.

With which of these groups do you have the most contact?

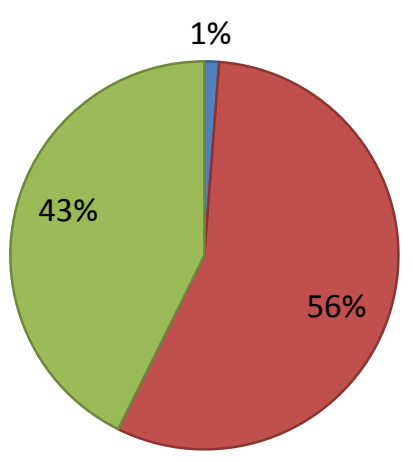

German students

$\square$ International students

$\square$ Students from home country

Figure 2. Most contact of international students in English-taught programmes. Source:Strenger (2019). 
The initial hypothesis that international students in these internationally oriented, Englishspeaking programmes lack contact with students of the host country, was verified by these results of the quantitative study.

In the qualitative interviews with students, this was supported further, sheding light on the very special situation of international students who migrate to Bochum for their entire master's studies. The interviews revealed that it is not only in their study environment, but also in their residential environment that international students stay mostly among themselves, for campus accommodation is organized for them during their first semester, and it is mostly foreigners living in the dorms on Bochum university campus. The very few students who have much contact to German students seem to be those who were able to find a housing situation apart from those dorms, in an appartment together with Germans.

One student summarizes her study experience in Germany as follows:

"I can be in this international bubble and it's cool - you keep meeting people from a lot of different places. But for me, it's interesting because you can be in Germany and really not learn the language and not experience the culture, it's weird.”

Based on the results of this investigation which clearly point to a lack of social capital with regard to their host country among international engineering students, the project ELLI2 in its second funding period since 2016 has established measures to improve the contact situation between international and German engineering students.

\section{Solution: Internationalization at home in RUB's Engineering Faculties}

Whereas traditional definitions of internationalization emphasized primarly on mobility of students, an increasing number of higher education experts estimate that mobile students will make up only a relatively small proportion while internationalization at home $(\mathrm{IaH})$ is a more convenient approach to summarize all internationalization activity aimed at the whole student body, including international and intercultural dimensions into the course of studies: Beelen; Jones (2015).

Engineering students in Germany still do go abroad less than average: German Academic Exchange Service (2017) and at the same time, it is an aim to increase the immigration and stay of highly educated engineering graduates due to labour shortages and the lack of suitably qualified doctoral candidates. Therefore, it was the project ELLI2's aim to implement concepts to bring international and local students together. By doing this, more internationalized experiences and more dialogue between students with different backgrounds for improving cultural competences and language skills for both groups should be promoted to benefit from the international potential already existing within the 
home university. In the following chapters, two measures with the most characteristic features and outcomes will be introduced.

\subsection{Tandem.MINT programme}

Tandem.MINT is a peer-learning concept for increasing intercultural competencies and language skills for local and international students of Natural Sciences \& Engineering (STEM) in order to increase IaH by a shared peer-learning-concept. In a classical tandem, two different native speakers practice the other one's language. The participants shall develop both their language and intercultural skills. As both tandem-partners are students of STEM-disciplines, they can refer to subject-specific contexts and improve their use of technical language. In the tandem-partnership, students practise working together professionally in multilingual and culturally heterogeneous teams. Thus, they acquire transferable skills for the increasingly globalised working environment in the field of Engineering and Natural Sciences. In the pilot project, students can either obtain credit points or a certificate. The pilot startet in summer semester 2018 with a high demand from engineering faculties with 41 of 45 applications coming from engineering courses. One third of the applications came from students of the English language master's programmes.

Most of the local students aimed to improve their English skills while almost all international students with advanced English skills wanted to improve their German skills with a tandem partner. As the demand for English language could not be met by English native speakers on the one hand and the native languages of the international students such as Hindi, Malayam, Arabic or Chinese were not demanded by the local students, the matching rules for the tandem programme had to be improved.

As the tandem.MINT programme is primarily a measure for increasing the dialogue between local and international students, this was an ideal challenge to meet students needs: The solution was to match advanced English-speaking international students for the target language. This way, a maximum of international students could be matched and these students experienced a setting on equal terms (as opposed to other dialogue concepts such as buddy programmes, which are rather one-way-benefit concepts). All students were informed about this change and almost none refused his or her participation.

At the end of the summer semester, all eight learning couples finished the programme successfully and they reported great intercultural and language development and emphasized on their benefits of learning with a partner he or she otherwise probably would not have met. The ongoing second pilot started in winter semester 2018/19. The demand from engineering students almost doubled and 16 pairs, mainly for English and German, are learning together. In a mid-term reflection session, all participating students reported that they benefit from this individualized learning where they can define contents and learning 
tempi individually. They value learning with a student partner who is not part of their regular peer-group as a realistic preparation for the international job market.

\subsection{Meetings of engineering student councils}

Another measure implemented successfully by the project ELLI2 is as simple as effective: organized meetings of all engineering student councils. As student councils are the multipliers to their student bodies, those meetings which are organized by the project are valuable in multiple ways: students from different study courses get the chance to network and to exchange views about common issues, challenges and events.

After implementing those meetings, council members asked the project to continue organizing and chairing the quarterly sessions as hosts. Since 2017, council members from the English-taught master's programmes join the meetings as well. Since then, the meetings are held in English. Usually, ELLI2 does not set the agenda for the meetings but staff members ask the councils prior to each meeting for issues to talk about. In addition to that, ELLI2 regularly introduces seminar offers or announcments within that circle.

When council members of the international master programmes started joining the meetings it turned out that students from both the German and English language study courses did not know much about each other until then. Some German council members for example did not even know about the existence of the international master's programmes at their faculties, whereas their international fellows did not know all the regular engineering study courses although there are some common seminars. In these meetings, the students discuss teaching evaluations and they look for solutions for shared problems. Besides, the ELLI2 student council meeting is a platform to organize joint events in order to network beyond the borders of a single study course. All council members report a significant benefit from those meetings. According to them, there were almost no points of contact at all with the other student groups before joining this overall student council meeting and they highly appreciate having an organized format now to increase the dialogue.

\section{Conclusions and Outlook}

While the internationalization of higher education in Germany has made great progress during the last two decades, the implementation of international study programmes alone does not seem to be enough to create an atmosphere of real internationality: The investigation results presented in this paper indicate that, when it comes to interaction between international and German students, there is much room for improvement. Different measures of ELLI2 were presented which aim at adding an international component to engineering education by increasing the dialogue between international and local students. 
The experiences made with these approaches indicate that $\mathrm{IaH}$ is working and highly appreciated by international and German students alike.

ELLI2 will go on until the end of 2020, by then, two more years of the Tandem.MINT programme and the council meetings will be evaluated. The project will strive for a continuation of its programmes within the RUB engineering faculties that goes beyond the funding period of the Quality Pact for Teaching and Learning. Through constant dialogue with stakeholders at central university level, in the faculties and with student representatives, it seems likely that pilot projects like Tandem.MINT and the organized council meetings will be continued. One interim result of both measures is that students do demand offers for getting in touch with each other but there are ongoing efforts to make in order to establish contact and dialogue on a regular basis which is independent from external support elements. The final objective should be to have more elements of internationalization at home within the curricula of all engineering courses.

\section{References}

Beelen, Jos; Jones, Elspeth (2015). Redefining Internationalization at Home. In: Curaj.Adrian et al. (Edts.) ( 2015). The European Higher Education Area Between Critical Reflections and Future Policies. Springer Open, Heidelberg New York, Dordrecht London, p. 59-72.

Bourdieu, Pierre (1983): Ökonomisches Kapital, kulturelles Kapital, soziales Kapital. In: Kreckel, Reinhardt (Ed.): Soziale Ungleichheiten. Soziale Welt. Sonderband 2. Göttingen, p. 183-198.

German Academic Exchange Service (DAAD) (2017). Wissenschaft weltoffen 2017: Facts and Figures on the International Nature of Studies and Research in Germany. Bielefeld: W. Bertelsmann Verlag.

German Academic Exchange Service (DAAD) (2019). Online database of international

study programmes in Germany: Homepage (last checked: $31^{\text {st }}$ January 2019): https://www.daad.de/deutschland/studienangebote/international-programs/en/

Maiworm, Friedhelm (Ed.) (2002): English-language-taught degree programmes in European higher education. Trends and success factors. Bonn: Lemmens (ACA Papers on international cooperation in education).

Strenger, Natascha; Frerich, Sulamith (2016): Implementation of International Master's Programmes in Engineering Education in Germany. 2nd International Conference on Higher Education Advances, HEAd'16, June 21 $1^{\text {st }}-23^{\text {rd }} 2016$, Valencia, Spain.

Strenger, Natascha (2019): Akademische Migration und internationale Masterstudiengänge in den Ingenieurwissenschaften. Dissertation. Bochum: Ruhr-Universität Bochum, Universitätsbibliothek (currently in the process of being published).

Teaching Quality Pact by the German Federal Government and States, "Qualitätspakt Lehre”, Homepage (last checked: 23th January 2019): http://www.qualitaetspaktlehre.de/en/index.php 